\title{
Anti-CD38 Monoclonal Antibody
}

National Cancer Institute

\section{Source}

National Cancer Institute. Anti-CD38 Monoclonal Antibody. NCI Thesaurus. Code C155321.

Any monoclonal antibody that is directed against the CD38 antigen. 